\title{
Channel Adjustments in Iranian Rivers: A Review
}

\author{
Somaiyeh Khaleghi ${ }^{1, *}$ and Nicola Surian ${ }^{2}$ (1) \\ 1 Department of Physical Geography, School of Earth Sciences, Shahid Beheshti University, \\ Tehran 1983969411, Iran \\ 2 Department of Geosciences, University of Padova, 35131 Padova, Italy; nicola.surian@unipd.it \\ * Correspondence: s_khaleghi@sbu.ac.ir; Tel.: +98-2990-5620
}

Received: 5 March 2019; Accepted: 26 March 2019; Published: 31 March 2019

\begin{abstract}
Channel adjustments in Iranian rivers have been intense over the last decades due to natural and human factors. Iran has six major basins, all with different climates, from very humid to very arid. This work is a review of the available studies and data about channel adjustments in Iranian rivers, and aims to reconstruct a first outline, at a national scale, of types, magnitude, and causes of adjustments. The results show that most of the rivers have undergone incision ( 1 to $2 \mathrm{~m}$ and, in some cases, up to 6 to $7 \mathrm{~m}$ ) and narrowing (from 19\% to $73 \%$ ), although widening (from $22 \%$ to $349 \%$ ) has occurred in some rivers. Narrowing is due to dams and sediment mining; widening is due to climate change and sediment mining. Incision is due to gravel and sand mining, dams, channelization, with in-channel mining being the main cause of incision. Channel adjustments have occurred in basins with different climates, but it seems that widening has been more intense in arid and semi-arid climates. Such adjustments have several negative effects (e.g., damage to bridges, degradation of river ecosystems, and instability of banks). The comparison between Iran and other countries shows that narrowing and incision have been the dominant processes in most of the rivers, while damming and in-channel mining have been used as the main controlling factors. Data about adjustments in Iranian rivers are neither homogeneous nor complete for all the rivers. This lack of completeness implies that our understanding of channel changes, and their causes, should be improved by further investigation.
\end{abstract}

Keywords: channel adjustments; incision; narrowing; human interventions; Iranian rivers

\section{Introduction}

Understanding of channel adjustment and controlling factors is very important for the interpretation of current channel conditions, prediction of future changes, and process-based river management $[1,2]$. Channel adjustments are driven both by natural (climate driven) and human factors. Human impact has produced remarkable channel changes, such as narrowing, incision, and changes to channel pattern [3-9]. The most common human interventions include channelization e.g., [10,11], dams e.g., [12-16], sediment mining [17,18], and land-use changes e.g., [19-35]. Natural factors include short-term climate changes e.g., [36], volcanic eruptions e.g., [37-39], large floods e.g., [40-42], and fires e.g., $[10,43,44]$.

Changes in river channels can have social and environmental effects, it can damage structures, increase the potential for flooding, decrease groundwater resources, and cause a reduction in the number of native species. Therefore, a better understanding of channel adjustments is crucial for river management, and to predict and mitigate the negative effects of such adjustments.

During the last few decades, river channels in Iran have been stressed by climate change and several human interventions, such as channelization, the diversion of water for flood mitigation and agriculture, damming, gravel and sand mining, and land-use changes. Although studies have been 
carried out on channel adjustments in Iranian rivers, a comprehensive review at national scale is lacking. By reviewing published articles and data, we addressed the following questions: (1) How much Iranian rivers have changed over the last decades (type and magnitude of change)? (2) What are the main causes of channel adjustments? (3) Are adjustments homogeneous throughout Iran or do some differences exist between the main geographic regions? Finally, channel adjustments of Iranian rivers were considered in a larger context, by comparing the situation in Iran with adjustments in other regions worldwide.

\section{Study Area}

The territory of Iran has an area of $1,648,000 \mathrm{~km}^{2}$, and is located at $25^{\circ}$ to $40^{\circ}$ northern latitude and $44^{\circ}$ to $64^{\circ}$ eastern longitude (Figure 1). Except the narrow plains along the Caspian Sea, the Persian Gulf, and Khouzestan Region, Iran is considered as a highland with an average elevation of $1000 \mathrm{~m}$ a.s.l. The lowest point in Iran is located in the northeast, in the salt plain of Shahdad on the margin of Lut Kavir, with an elevation of $350 \mathrm{~m}$. The highest point in Iran is Mount Damavand in the Alborz Mountain range, with a height of $5774 \mathrm{~m}$. From a global tectonic point of view, Iran is part of the Alpine-Himalayan orogenic belt that extends from the Atlantic Ocean to the Western Pacific.

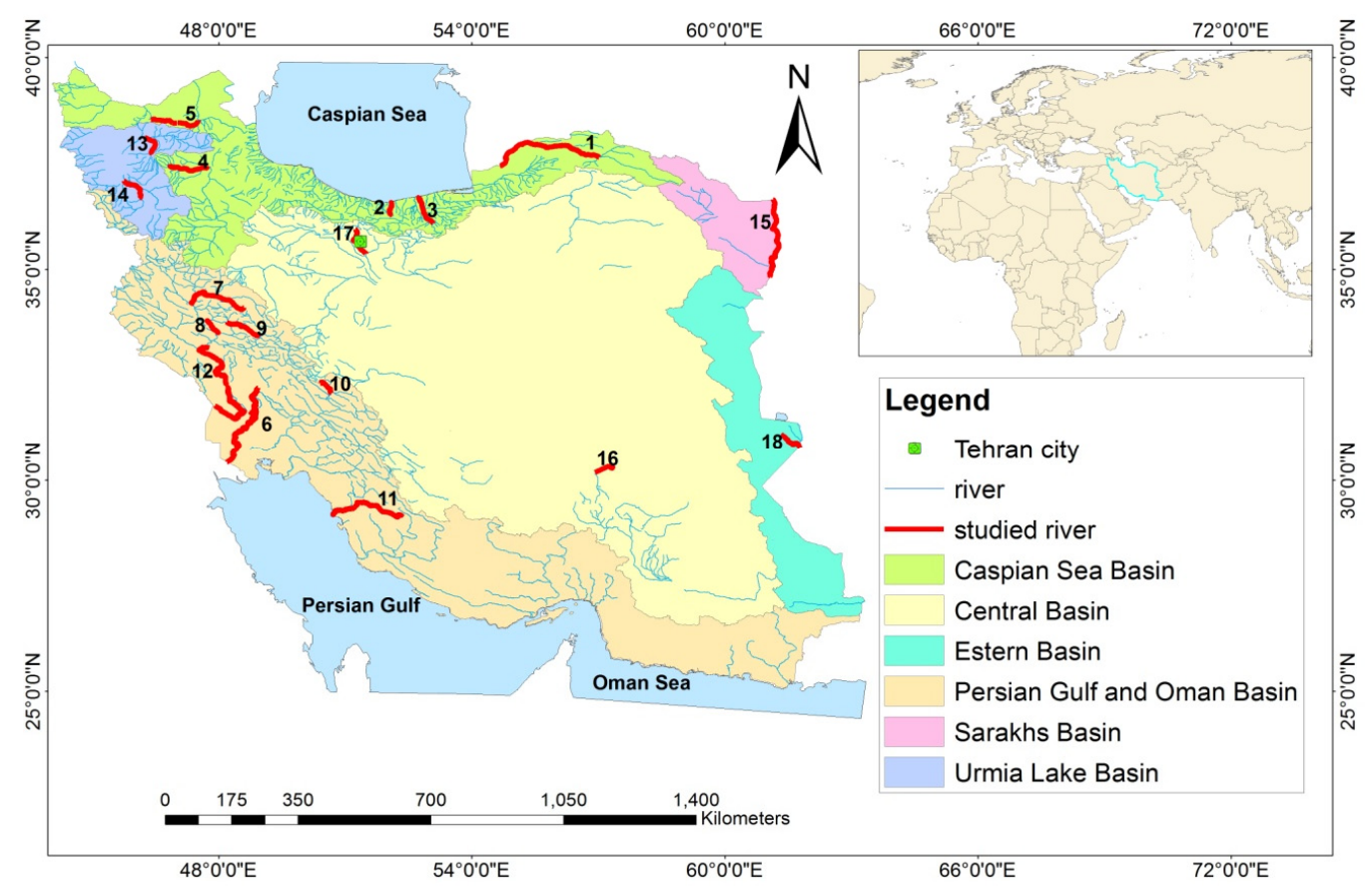

Figure 1. Location map showing Iranian river network, main drainage basins, and rivers analyzed in this study.

Iran features very diverse climatic and geographic characteristics. The highest temperature in the Persian Gulf area can reach up to $53{ }^{\circ} \mathrm{C}$ in summer, and the lowest temperature in the northwestern part of Iran can reach up to $-40{ }^{\circ} \mathrm{C}$ in winter [45]. The average annual precipitation is estimated at $250 \mathrm{~mm}$, varying from $50 \mathrm{~mm}$ in some areas of the central water basin, to more than $1600 \mathrm{~mm}$ in some coastal areas near the Caspian Sea [46]. The climate ranges from very humid to very arid, but in the majority of the country it is very arid and arid (Figure 2).

According to the classification of the Ministry of Energy, Iranian rivers can be grouped into six major drainage basins: 1-Caspian Sea Basin; 2-Persian Gulf and Oman Sea Basin; 3-Urmia Lake Basin; 4-Central Basin; 5-Eastern Basin (Hamoon); 6-Sarakhs Basin. All these basins are interior, except for the Persian Gulf and Oman Sea Basin. We found information about channel adjustments for 18 rivers, which are mainly located in the Persian Gulf and Oman Sea Basin (seven rivers) and the Caspian Basin (five rivers) (Figure 1). The main hydrological and physiographic characteristics of the 
rivers analyzed in this study are summarized in Table 1 . The hydrological regime of all studied rivers is perennial.

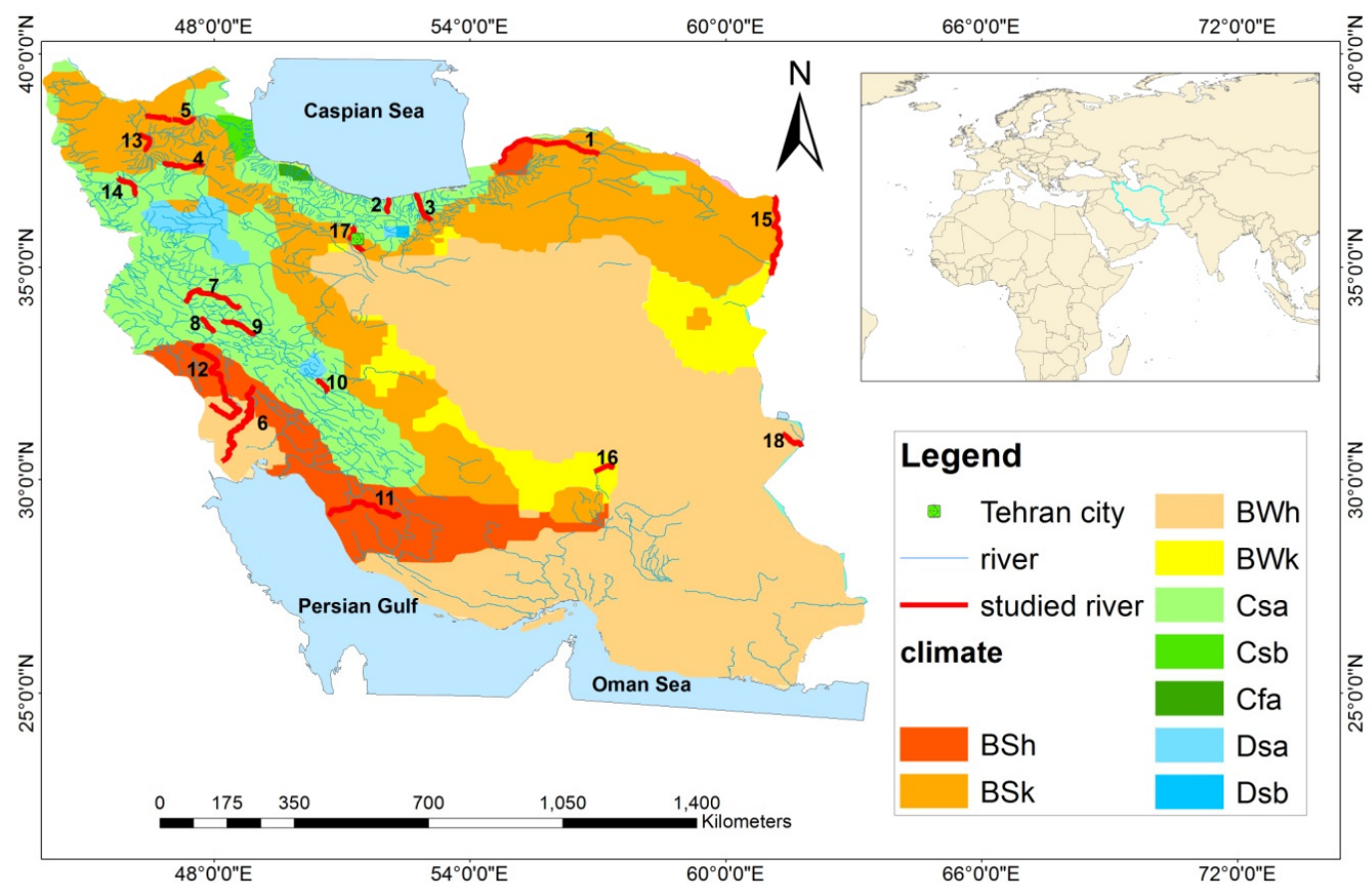

Figure 2. Climatic condition of Iran (1990 to 2014) according to the Koppen-Geiger classification (BSh: Semi-arid (steppe) desert and hot; BSk: Semi-arid (steppe) desert and cold; BWh: Arid desert and hot; BWk: Arid desert and cold; Csa: Mediterranean hot summer; Csb: Mediterranean warm/cool summer; Cfa: Humid subtropical; Dsa: Hot summer continental; Dsb: Warm summer continental or hemiboreal) [47].

Table 1. Hydrological and physiographic characteristics of the studied rivers (from: [48-65]).

\begin{tabular}{|c|c|c|c|c|c|c|}
\hline ID & River & $\begin{array}{c}\text { Drainage } \\
\text { Basin Area } \\
\left(\mathbf{k m}^{2}\right)\end{array}$ & Length (km) & $\begin{array}{c}\text { Basin } \\
\text { Relief }^{*}(\mathrm{~m})\end{array}$ & $\begin{array}{l}\text { Mean Annual } \\
\text { Precipitation } \\
\left(\mathrm{mm} \mathrm{yr}^{-1}\right)\end{array}$ & $\begin{array}{c}\text { Mean Annual } \\
\text { Discharge } \\
\left(\mathrm{m}^{3} \mathrm{~s}^{-1}\right)\end{array}$ \\
\hline 1 & Atrak & 27,546 & 214 & 2508 & 350 & 12.6 \\
\hline 2 & Lavij & 146 & 38 & 3200 & 600 & 1.7 \\
\hline 3 & Talar & 2478 & 121 & 3782 & 820 & 13.7 \\
\hline 4 & Qaranqu & 3593 & 190 & 2637 & 374 & 8 \\
\hline 5 & Ahar Chai & 3035 & 132 & 2864 & 330 & 1.3 \\
\hline 6 & Karoon & 60,737 & 800 & 4536 & 660 & 400 \\
\hline 7 & Gamasiyab & 7770 & 270 & 2219 & 420 & 150 \\
\hline 8 & Kashkan & 9120 & 231 & 2500 & 550 & 33.2 \\
\hline 9 & Horroud & 1123 & 83 & 2000 & 500 & 2.5 \\
\hline 10 & Khoshkehroud & 250 & 17 & 1000 & 461 & 66 \\
\hline 11 & Dalaki & 5210 & 150 & 3000 & 325 & 13.7 \\
\hline 12 & Karkheh & 51,482 & 900 & 3642 & 477 & 167 \\
\hline 13 & Lighvan Chai & 142 & 28 & 1690 & 292 & 0.8 \\
\hline 14 & Zarrineroud & 11,729 & 217 & 2000 & 330 & 62.1 \\
\hline 15 & Harriroud & 70,600 & 900 & 950 & 188 & 22.3 \\
\hline 16 & Dehbala-Kerman & 89 & 20 & 1500 & 153 & - \\
\hline 17 & Kan & 224 & 33 & 2496 & 300 & 2.7 \\
\hline 18 & Sistan & 2500 & 72 & 14 & 52 & 69.4 \\
\hline
\end{tabular}

* Basin relief is a difference between maximum elevation in the basin and elevation at basin outlet.

\section{Materials and Methods}

A review of studies about morphological changes in Iranian rivers was carried out. It is worth noting that this is the first review about this topic in Iran. We looked for studies, both in English 
and Persian, dealing with channel changes during the last few decades. The review was focused on: (1) Type and magnitude of morphological changes, (2) causes of changes, (3) effects of changes on structures and environment.

Data were found for 18 rivers and allowed for a description of each river by the following aspects: Channel morphology; morphological changes; location and time of changes; causes of changes. Such aspects were defined after a preliminary screening of available data, taking into account possible limitations (e.g., lack of information) of the studies that we analyzed. As for channel morphology, we opted for just two typologies, single-thread and multi-thread. Morphological changes refer mainly to change in channel width (narrowing and widening) and in bed-level (incision and aggradation). The time of change (the period of time when channel changes have taken place) is crucial information since it allows for an assessment of the magnitude of processes that have occurred. Causes of changes are those mentioned in the studies, therefore we relied on original interpretations for this aspect, as well as for the others. For sediment mining, one of the major causes of changes in Iranian rivers, was if activity was carried out within the channel (in-stream mining). If mining activity was not clearly described, not indicating if activity was carried within the channel or in the fluvial corridor, this was simply reported in our analysis as 'mining'. Climate was defined for each river, as it was an aim of this study to investigate the possible role varying climate has, specifically if relation to channel adjustments (e.g., arid vs. temperate climate).

Finally, to facilitate analysis and interpretation of the dataset, a numerical identifier (ID) was associated to each river or river segment.

\section{Results}

\subsection{Type and Magnitude of Channel Changes}

As for planform changes, both narrowing and widening have occurred in cases 13 and 7, respectively (Table 2). Narrowing ranged between $19 \%$ and $84 \%$ (Figure 3 ) and, in some cases, was shown to be up to $300 \mathrm{~m}$ (e.g., some reaches of the Karun River). Widening ranged between $22 \%$ and $349 \%$ and has been shown to be more than $100 \mathrm{~m}$ in some rivers (e.g., Gamasiyab and Harirroud rivers). Furthermore, changes in channel pattern have occurred in some reaches (Table 2): From braided to meandering and then straight (e.g., Ahar Chai River); from meandering to braided (e.g., Gamasiyab River).
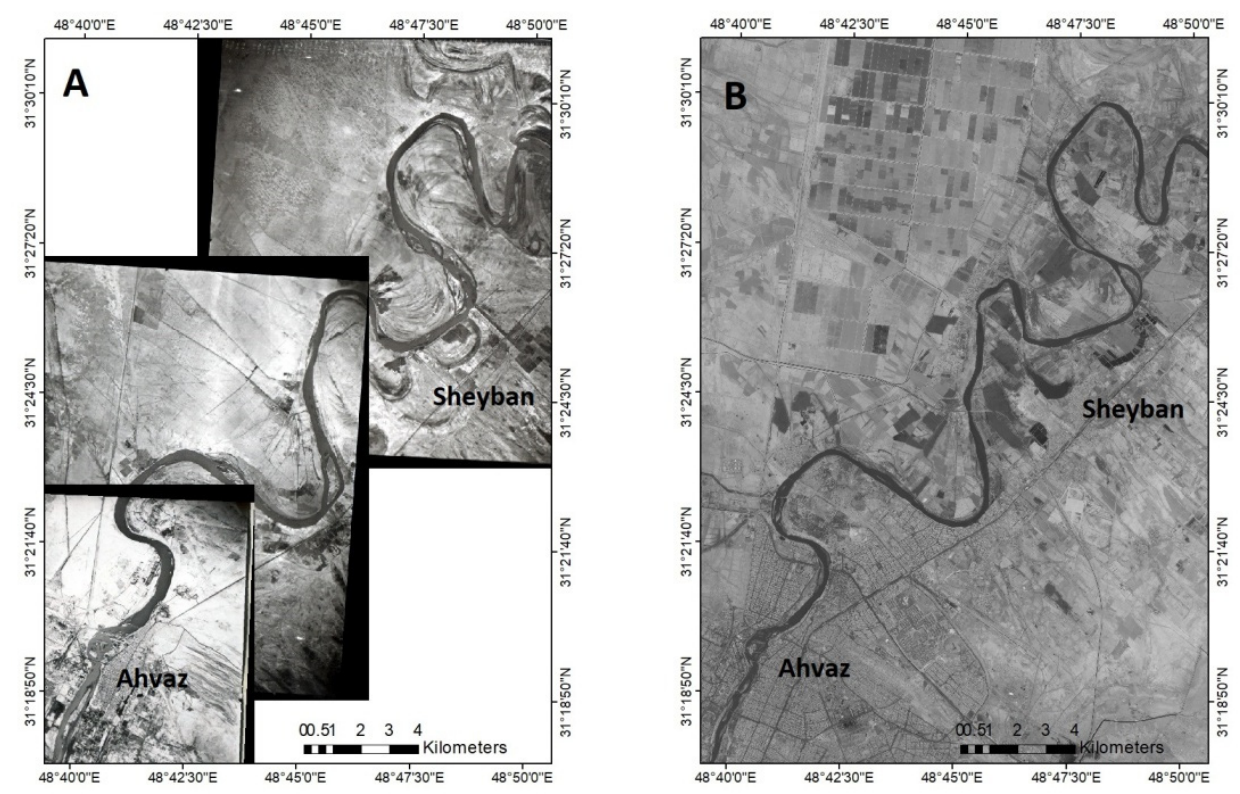

Figure 3. Channel narrowing in the Karun River due to human intervention, especially dam construction [66]: (A) aerial photograph of 1954; (B) IRS imagery of 2006. 
As for bed-level changes, incision was observed in eight rivers, while aggradation was seen in three rivers (Table 2). Incision has been commonly seen at 1 to $2 \mathrm{~m}$, but in some reaches, up to 6 to $7 \mathrm{~m}$ was seen (e.g., Talar and Khoshkehroud rivers) (Figure 4). An estimate of aggradation is not available.

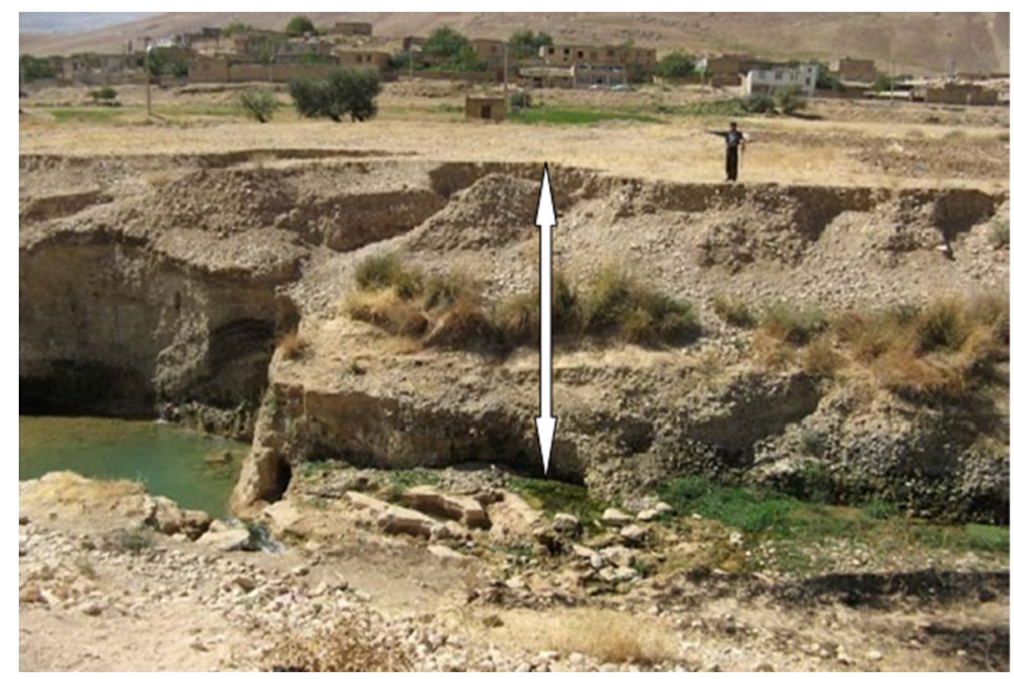

Figure 4. Channel incision in the Khoshkehroud River [65].

Coupling of processes, both planform and bed-level changes, was available for ten cases out of 21 (Table 2). Narrowing has been associated with incision and aggradation in cases 5 and 2, respectively, while widening with incision and bed-level stability was seen in case 2 and 1, respectively.

Some channel changes started in the 1950s to 1960s, whereas some others begin at the beginning of this century. This suggests that, overall, the morphological changes have been quite intense since they occurred in a time period of 50 to 60 years and, in some cases, of only 15 to 20 years. 
Table 2. Channel adjustments in Iranian rivers and relative causes

\begin{tabular}{|c|c|c|c|c|c|c|c|}
\hline ID & River & $\begin{array}{l}\text { Channel } \\
\text { Morphology }\end{array}$ & Morphological Changes & $\begin{array}{c}\text { Location and Time of } \\
\text { Changes }\end{array}$ & Causes & $\begin{array}{l}\text { Climate Type } \\
\text { (Koppen-Geiger } \\
\text { Classification) }\end{array}$ & Reference \\
\hline & & \multicolumn{6}{|c|}{ Caspian Sea Basin } \\
\hline 1 & Atrak & Single thread & $\begin{array}{l}\text { Widening (up to } 11 \mathrm{~m} \text { ) } \\
\text { depth (no changes) }\end{array}$ & $\begin{array}{l}\text { Alluvial plain reaches; } \\
1967 \text { to } 2001\end{array}$ & $\begin{array}{l}\text { Changes of hydrology; changes of } \\
\text { land use and cultivation pattern } \\
\text { in floodplain }\end{array}$ & BSk & [62] \\
\hline 2 & Lavij & Single thread & $\begin{array}{l}\text { Widening ( } 1 \text { to } 24 \mathrm{~m}) \\
\text { incision }(0.2 \text { to } 1.8 \mathrm{~m})\end{array}$ & $\begin{array}{l}\text { Alluvial plain reaches } \\
\text { (150 km); } \\
2008 \text { to } 2011\end{array}$ & $\begin{array}{l}\text { In-stream gravel and sand mining; } \\
\text { channelization; river engineering }\end{array}$ & Csa & [52] \\
\hline $3 a *$ & Talar & $\begin{array}{l}\text { Single thread and } \\
\text { multi-thread }\end{array}$ & $\begin{array}{l}\text { Incision ( } 3 \mathrm{~m} \text { in most } \\
\text { reaches) }\end{array}$ & $\begin{array}{l}\text { Alluvial plain reaches } \\
\text { (90 km); } \\
1971 \text { to } 2005\end{array}$ & Gravel and sand mining & Csa & [57] \\
\hline $3 b^{*}$ & Talar & $\begin{array}{l}\text { Single thread and } \\
\text { multi-thread }\end{array}$ & $\begin{array}{l}\text { Narrowing (on average } \\
84 \% \text { ), braided index } \\
\text { decreased and the sinuosity } \\
\text { index increased }\end{array}$ & $\begin{array}{l}1955 \text { to } 2013 \\
(11.5 \mathrm{~km})\end{array}$ & $\begin{array}{l}\text { Land-use changes from forest land } \\
\text { and riparian vegetation to } \\
\text { residential lands }\end{array}$ & Csa & [67] \\
\hline $3 c^{*}$ & Talar & $\begin{array}{l}\text { Single thread and } \\
\text { multi-thread }\end{array}$ & $\begin{array}{l}\text { Narrowing (on average } \\
25.5 \mathrm{~m} \text { ), aggradation }\end{array}$ & 1968 to 2013 & $\begin{array}{l}\text { Land-use changes increases of } \\
192 \% \text { and } 622 \% \text { have been } \\
\text { observed for orchards and } \\
\text { residential areas; forest and } \\
\text { riparian vegetation decreased }\end{array}$ & Csa & [68] \\
\hline 4 & Qaranqu & Single thread & $\begin{array}{l}\text { Widening ( } 70 \text { to } 100 \mathrm{~m} \text { in } \\
\text { some cases); incision } \\
(0.75 \text { to } 2.5 \mathrm{~m})\end{array}$ & $\begin{array}{l}\text { Mountain reach }(20 \mathrm{~km}) ; \\
2008 \text { to } 2013\end{array}$ & $\begin{array}{l}\text { In-stream gravel and } \\
\text { sand mining; Dam }\end{array}$ & BSk & [49] \\
\hline 5 & Ahar Chai & Single thread & $\begin{array}{c}\text { Incision (on average } 0.6 \mathrm{~m} \\
\text { downstream of dam); } \\
\text { narrowing (on average } 8 \mathrm{~m} \\
\text { downstream of dam); from } \\
\text { braided to meandering and } \\
\text { then straight }\end{array}$ & $\begin{array}{l}\text { Mountain reaches } \\
(35 \mathrm{~km}) ; 1978 \text { to } 2005\end{array}$ & Dam & BSk & [50] \\
\hline
\end{tabular}


Table 2. Cont

\begin{tabular}{|c|c|c|c|c|c|c|c|}
\hline ID & River & $\begin{array}{l}\text { Channel } \\
\text { Morphology }\end{array}$ & Morphological Changes & $\begin{array}{l}\text { Location and Time of } \\
\text { Changes }\end{array}$ & Causes & $\begin{array}{l}\text { Climate Type } \\
\text { (Koppen-Geiger } \\
\text { Classification) }\end{array}$ & Reference \\
\hline & & \multicolumn{6}{|c|}{ Persian Gulf and Oman Basin } \\
\hline $6 a *$ & Karoon & Single thread & $\begin{array}{l}\text { Narrowing (on average } \\
143 \mathrm{~m} \text { ), aggradation }\end{array}$ & $\begin{array}{l}\text { Mollasani to Farsiat; } \\
\text { Alluvial plain reaches } \\
(110 \mathrm{~km}) ; 1995 \text { to } 2011\end{array}$ & $\begin{array}{l}\text { Dam; bridge; land-use changes in } \\
\text { floodplain; human interventions }\end{array}$ & BWh & [66] \\
\hline $6 b^{*}$ & Karoon & Single thread & $\begin{array}{l}\text { Narrowing (on average } \\
18 \mathrm{~m} \text { ) }\end{array}$ & $\begin{array}{l}\text { From Gotvand to } \\
\text { Shoshtar; } \\
\text { Alluvial plain reaches } \\
(128 \mathrm{~km}) ; \\
1989 \text { to } 2008\end{array}$ & $\begin{array}{l}\text { Land-use and land-cover changes; } \\
\text { dam; gravel mining }\end{array}$ & BSh & [34] \\
\hline 7 & Gamasiyab & $\begin{array}{l}\text { Single thread and } \\
\text { multi-thread }\end{array}$ & $\begin{array}{l}\text { Widening (on average } \\
122 \mathrm{~m} \text { ); changes in channel } \\
\text { pattern (from meandering } \\
\text { to braided) }\end{array}$ & $\begin{array}{l}\text { Alluvial plain reach; } \\
1955 \text { to } 2010\end{array}$ & $\begin{array}{c}\text { Fluctuation peak discharges; } \\
\text { land-use changes }\end{array}$ & Csa & [58] \\
\hline 8 & Kashkan & $\begin{array}{l}\text { Single thread and } \\
\text { multi-thread }\end{array}$ & $\begin{array}{l}\text { Narrowing in most reaches } \\
(6 \text { to } 66 \mathrm{~m})\end{array}$ & $\begin{array}{c}\text { Mountain reach }(14 \mathrm{~km}) ; \\
2002 \text { to } 2009\end{array}$ & $\begin{array}{l}\text { In-stream gravel and sand mining; } \\
\text { bridge; diversions; changes of } \\
\text { hydrology; hydraulic structures }\end{array}$ & Csa & [61] \\
\hline 9 & Horroud & $\begin{array}{l}\text { Single thread and } \\
\text { multi-thread }\end{array}$ & $\begin{array}{l}\text { Widening (on average } 20 \text { to } \\
37 \mathrm{~m} \text { in alluvial reaches and } \\
1 \mathrm{~m} \text { in mountain reach) }\end{array}$ & $\begin{array}{l}\text { Mountain and alluvial } \\
\text { plain reaches }(83 \mathrm{~km}) \text {; } \\
1955 \text { to } 2007\end{array}$ & $\begin{array}{l}\text { Human interventions and } \\
\text { development of cultivation and } \\
\text { residential land }\end{array}$ & Csa & [63] \\
\hline 10 & Khoshkehroud & Single thread & $\begin{array}{l}\text { Incision (1 to } 6.5 \mathrm{~m}) \\
\text { narrowing (5 to } 40 \mathrm{~m})\end{array}$ & $\begin{array}{l}\text { Alluvial plain }(5 \mathrm{~km}) \\
2001 \text { to } 2006\end{array}$ & In-stream gravel and sand mining & Csa & [65] \\
\hline 11 & Dalaki & Single thread & $\begin{array}{l}\text { Narrowing (on average } \\
23 \mathrm{~m} \text { in most reaches) }\end{array}$ & $\begin{array}{l}\text { Mountain and alluvial } \\
\text { plain reaches; } \\
1975 \text { to } 2013\end{array}$ & $\begin{array}{l}\text { Natural factor (loess lithology and } \\
\text { low slope, drought), dam; gravel } \\
\text { and sand mining from floodplain }\end{array}$ & BSh & [54] \\
\hline 12 & Karkheh & Single thread & $\begin{array}{l}\text { Narrowing (on average } \\
17 \mathrm{~m} \text { ); Incision on (average } \\
0.1 \mathrm{~m} \text { in most reaches) }\end{array}$ & $\begin{array}{l}\text { Alluvial plain }(218 \mathrm{~km}) \\
2002 \text { to } 2014\end{array}$ & Dam & BSh \& BWh & [48] \\
\hline
\end{tabular}


Table 2. Cont

\begin{tabular}{|c|c|c|c|c|c|c|c|}
\hline ID & River & $\begin{array}{c}\text { Channel } \\
\text { Morphology }\end{array}$ & Morphological Changes & $\begin{array}{c}\text { Location and Time of } \\
\text { Changes }\end{array}$ & Causes & $\begin{array}{l}\text { Climate Type } \\
\text { (Koppen-Geiger } \\
\text { Classification) }\end{array}$ & Reference \\
\hline & & \multicolumn{6}{|c|}{ Urmia Lake Basin } \\
\hline 13 & Lighvan Chai & Single thread & $\begin{array}{l}\text { Incision (up to } 1 \mathrm{~m} \text { ); } \\
\text { narrowing (up to } 18 \mathrm{~m} \text { ) in } \\
\text { few cross sections in the } \\
\text { upstream part of the study } \\
\text { reach, widening in few } \\
\text { cross sections in the } \\
\text { downstream part. }\end{array}$ & $\begin{array}{l}\text { Mountain reaches } \\
(15 \mathrm{~km}) ; \\
2000 \text { to } 2012\end{array}$ & $\begin{array}{l}\text { Channelization, increase of peak } \\
\text { discharges (due to an increase of } \\
\text { precipitation and } \\
\text { land-use changes) }\end{array}$ & BSk & [55] \\
\hline \multirow[t]{2}{*}{14} & Zarineroud & Single thread & Narrowing (13 m) & $\begin{array}{l}\text { Alluvial plain reach; } \\
1955 \text { to } 2003\end{array}$ & Dam & Csa & [51] \\
\hline & & \multicolumn{6}{|c|}{ Sarakhs Basin } \\
\hline \multirow[t]{2}{*}{15} & Harirroud & $\begin{array}{l}\text { Single thread and } \\
\text { multi-thread }\end{array}$ & $\begin{array}{l}\text { Widening (on average } \\
115 \mathrm{~m} \text { ) }\end{array}$ & $\begin{array}{l}\text { Mountain and alluvial } \\
\text { plain reaches; } \\
1974 \text { to } 2011\end{array}$ & $\begin{array}{l}\text { Increasing discharge and } \\
\text { sediment; land-use changes in } \\
\text { floodplain; human interventions }\end{array}$ & BSk & [53] \\
\hline & & \multicolumn{6}{|c|}{ Central Basin } \\
\hline 16 & Dehbala-kerman & Single thread & Widening (on average $84 \mathrm{~m}$ ) & $\begin{array}{c}\text { Mountain and alluvial } \\
\text { plain reaches (10 km); } \\
1988 \text { to } 2011\end{array}$ & In-stream gravel and sand mining & BWk & [56] \\
\hline \multirow[t]{2}{*}{17} & Kan & Single thread & $\begin{array}{l}\text { Incision (up to } 2 \mathrm{~m} \text { ); } \\
\text { narrowing }\end{array}$ & $\begin{array}{l}\text { Alluvial plain reaches; } \\
1969 \text { to } 2009\end{array}$ & In-stream gravel and sand mining & BSk & [59] \\
\hline & & \multicolumn{6}{|c|}{ East Basin } \\
\hline 18 & Sistan & Single thread & $\begin{array}{c}\text { Narrowing (on average } \\
183 \mathrm{~m} \text { ) }\end{array}$ & $\begin{array}{l}\text { Alluvial plain reaches; } \\
1956 \text { to } 2008\end{array}$ & Dam & BWh & [64] \\
\hline
\end{tabular}

${ }^{*} \mathrm{a}, \mathrm{b}$, and $\mathrm{c}$ are the different reaches of the same river. 


\subsection{Causes and Effects of Channel Adjustments}

All the analyzed studies made an attempt to identify the causes of channel adjustments. Both anthropic (e.g., sediment mining, dams, land-use changes) and natural (climate change) causes have been recognized. Channel adjustments have been related to a combination of different causes in 11 cases, whereas to a single cause in ten cases (Table 2). As for multiple causes, a combination of anthropic and natural factors were identified in five cases, whereas a combination of different anthropic factors were identified in six cases. As for single causes, both sediment mining and dams have been identified in four cases, whereas land-use change was identified in two cases.

The next step in our analysis of the dataset was to identify the main causes of adjustments. Being aware of some limitations, namely that we had to select a main factor for those rivers characterized by multiple causes, and the relatively small size of the dataset, this analysis could be useful to explore possible relationships between causes (e.g., controlling factors) and channel adjustments. Three causes turned out to be the dominant causes in 16 out of 18 rivers (Figures 5 and 6): Gravel and sand mining (river ID: 2, 3, 4, 8, 10, 16, 17); dams (ID: 5, 6, 12, 14, 18); climate change (ID: 7, 9, 11, 15). Channelization and land-use change (coupled with climate change) were identified for the other two rivers of the dataset. If channel response to gravel and sand mining is straightforward in terms of bed-level change (all the available case studies show mining associated with channel incision; Figure 6), it is not in terms of planform change. In fact, the response to sediment mining was both narrowing and widening (Figure 5). On the contrary, the response to dams seems more direct, since narrowing and incision have been observed in all the rivers with such human disturbance. Finally, climate change seems to mainly induce channel widening (Figure 5).

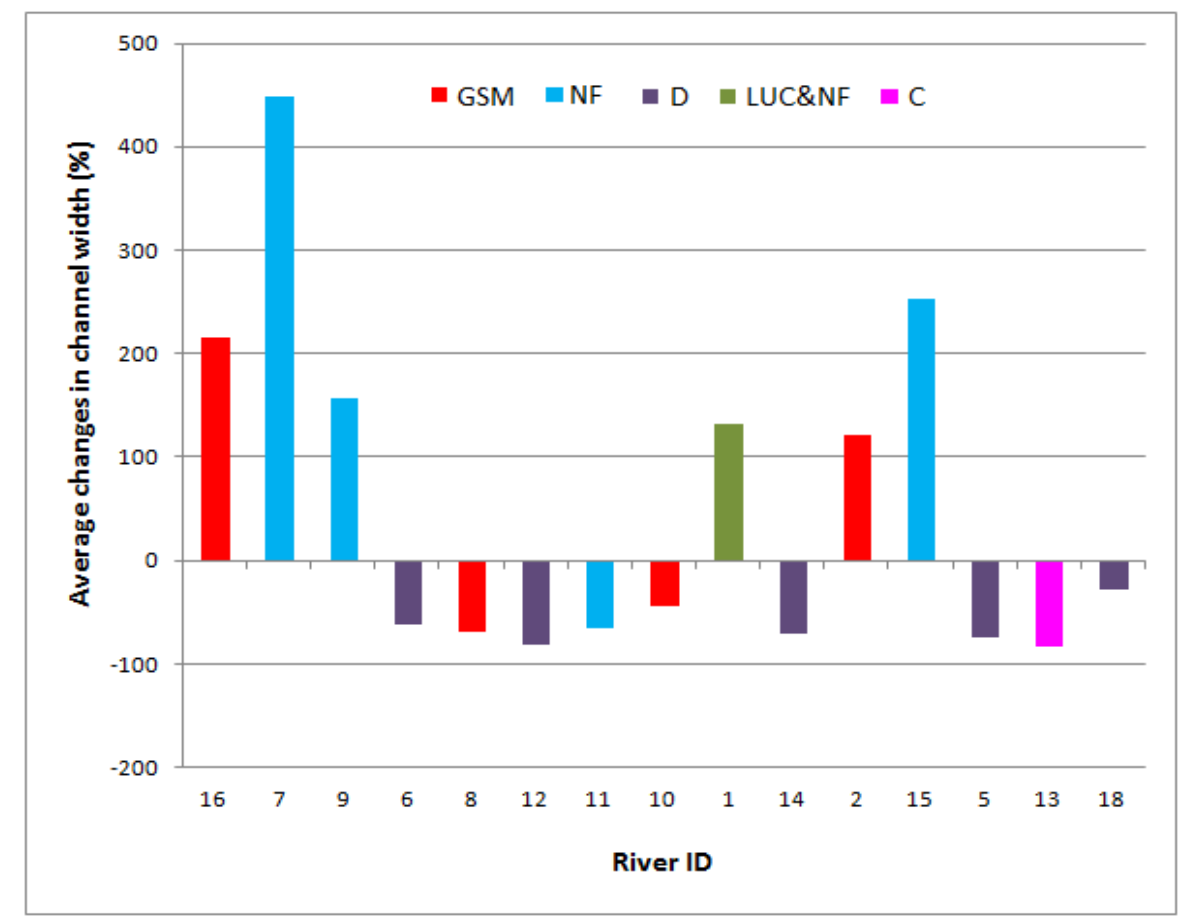

Figure 5. Changes in channel width and relative causes in Iranian rivers. GSM: Gravel and sand mining, NF: Natural factors, D: Dam, LUC\&NF: Land-use change and natural factors, C: Channelization.

Morphological changes in river channels may have negative effects on hydraulic structures, infrastructure, agricultural lands, and the environment. Gravel and sand mining has led to the instability of banks, damage to structures, increasing flood hazard and potential damages to bridges (Figure 7). Widening of the channel has led to a loss of agricultural land (e.g., Harirroud River). Finally, it is likely that channel changes have had effects on environment and ecosystems, but such effects were not evaluated in the available studies. 


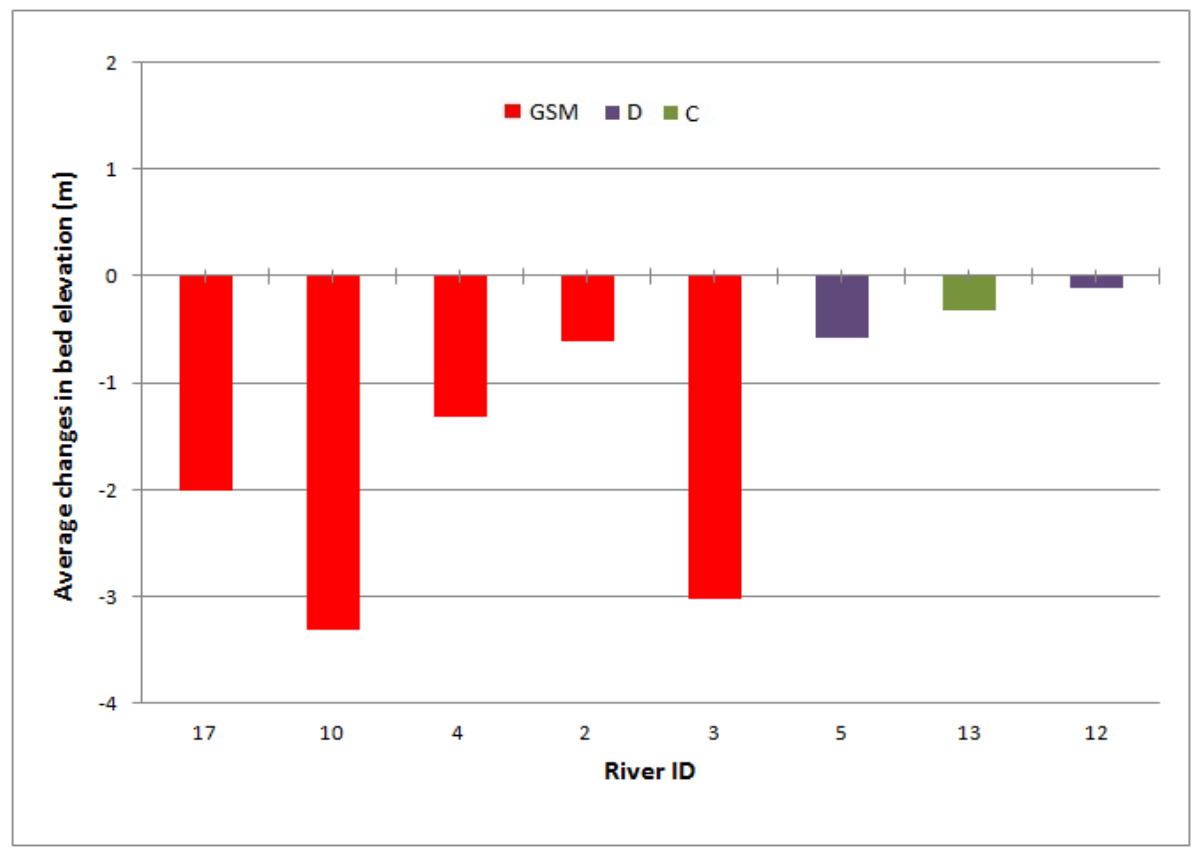

Figure 6. Changes in bed elevation and relative causes in Iranian rivers. GSM: Gravel and sand mining, D: Dam, C: Channelization.
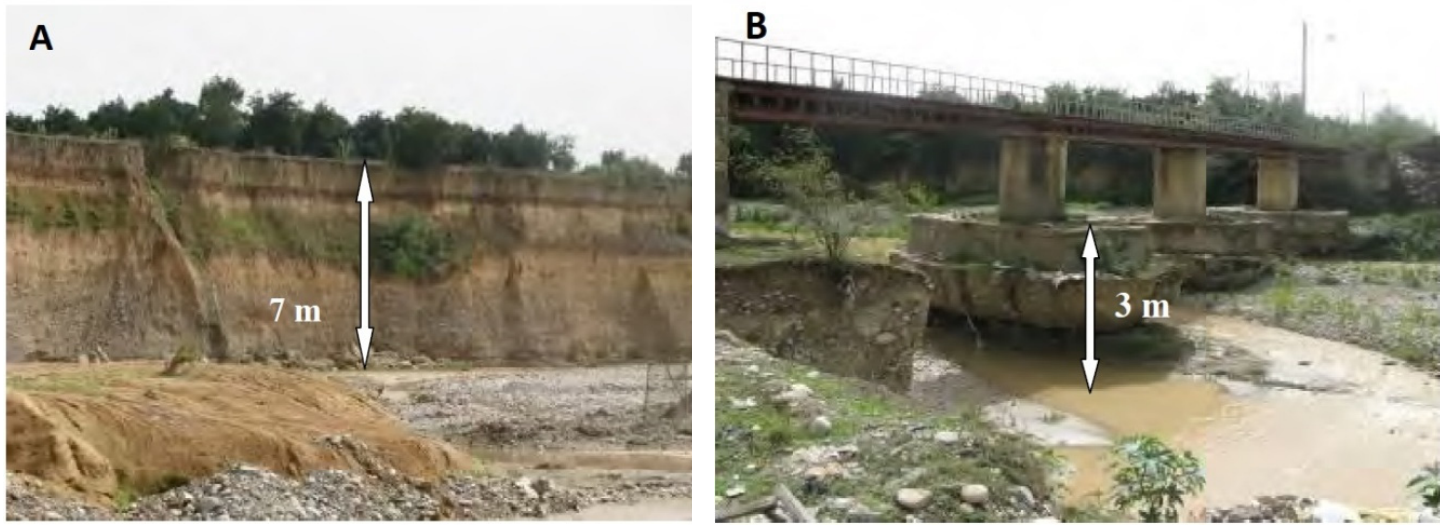

Figure 7. Channel incision due to in-stream gravel and sand mining (A); Effects of channel incision along the Talar River and effects on bridge stability (B) [57].

\section{Discussion}

\subsection{Channel Adjustment in Iranian Rivers and Comparison with Other Rivers Worldwide}

Channel adjustment has been remarkable in Iranian rivers (a narrowing up to $73 \%$ and incision up 6 to $7 \mathrm{~m}$ ). These channel adjustments bring to mind the question whether such adjustments in Iran are similar to those that have occurred in other rivers worldwide. Studies about rivers in Europe (e.g., Italy, France, Spain, UK, Poland, and Hungary), and elsewhere (China and USA) show that narrowing and incision have been the dominant processes in these rivers, and that sediment mining, damming, channelization, over grazing, and land-use changes are the main controlling factors (Table 3). As for planform adjustments, narrowing was the dominant process in Iranian rivers, but it is worth noting that widening took place in 7 out of 20 cases (Table 2 and Figure 3). Similarly, in regard to bed-level changes, incision was dominant, but aggradation occurred in 3 out of 11 cases (Table 2 and Figure 4). As for controlling factors, sediment mining and damming are the most important in Iranian rivers, as 
well as in several rivers worldwide, although climate change turned out to be the key factor in 4 out of 18 rivers (Figures 5 and 6 ).

Table 3. Channel changes due to human activities: Case studies from different countries and environments.

\begin{tabular}{|c|c|c|c|c|}
\hline Region & Channel Adjustments & Causes & $\begin{array}{l}\text { Climate Type } \\
\text { (Koppen-Geiger } \\
\text { Classification) }\end{array}$ & Reference \\
\hline Spain & $\begin{array}{l}\text { Incision (more than } 2 \mathrm{~m} \text { ) } \\
\text { narrowing, changes in channel } \\
\text { pattern (from braided to } \\
\text { meandering) }\end{array}$ & $\begin{array}{l}\text { Reforestation and expansion of } \\
\text { shrubs, depopulation and } \\
\text { farmland abandonment resulting } \\
\text { in plan recolonization in formerly } \\
\text { cultivated areas }\end{array}$ & $\mathrm{Cfb}^{*}$ & [69] \\
\hline Spain & $\begin{array}{c}\text { Incision (4 to } 6 \mathrm{~m} \text { ); changes in } \\
\text { channel pattern (from braided to } \\
\text { straight); in some reaches } \\
\text { widening and some reached } \\
\text { narrowing }\end{array}$ & $\begin{array}{l}\text { Gravel mining; dams; } \\
\text { afforestation; water withdrawal } \\
\text { for irrigation }\end{array}$ & $\mathrm{Cfb}$ & [18] \\
\hline Europe & $\begin{array}{l}\text { Narrowing; incision; changes in } \\
\text { channel pattern (from braiding to } \\
\text { wandering or single thread) }\end{array}$ & $\begin{array}{l}\text { Human interventions: Gravel and } \\
\text { sand mining }\end{array}$ & $\mathrm{Cfb}$ & [3] \\
\hline China & $\begin{array}{l}\text { Incision (1.6 to } 11 \mathrm{~m},>10 \mathrm{~m} \text { in the } \\
\text { deepest cut); narrowing (up to } \\
150 \mathrm{~m} \text { at Sanshui) }\end{array}$ & $\begin{array}{l}\text { Declining rainfall; dam } \\
\text { constructions; water diversion; } \\
\text { reforestation and afforestation; } \\
\text { sediment mining }\end{array}$ & $\mathrm{Cfb}$ & [70] \\
\hline New Mexico & Narrowing ( 5 to $103 \mathrm{~m}$ ) & $\begin{array}{l}\text { Decreasing peak flows; the } \\
\text { implementation of flood control } \\
\text { and engineering works; climate } \\
\text { change, droughts }\end{array}$ & BSk & [71] \\
\hline Scotland & $\begin{array}{l}\text { Narrowing (on average } 34 \% \text { ); } \\
\text { incision }\end{array}$ & Flood embankment construction & $\mathrm{Cfb}$ & [72] \\
\hline $\begin{array}{l}\text { Northern } \\
\text { England }\end{array}$ & $\begin{array}{l}\text { Incision (average } 1 \mathrm{~m} \text { and up to } \\
2 \mathrm{~m} \text { ); narrowing }\end{array}$ & $\begin{array}{l}\text { Gravel extraction, magnitude } \\
\text { flood with high frequency }\end{array}$ & $\mathrm{Cfb}$ & [73] \\
\hline Poland & $\begin{array}{l}\text { Incision ( } 1 \text { to } 3.8 \mathrm{~m}) \text {; narrowing } \\
\text { (10\% up to } 70 \%)\end{array}$ & $\begin{array}{l}\text { Channelization; decrease in } \\
\text { sediment supply; in-stream gravel } \\
\text { mining; dam, land-use changes }\end{array}$ & $\mathrm{Dfb} * *$ & {$[74,75]$} \\
\hline Hungary & $\begin{array}{l}\text { Incision (up to } 3.8 \mathrm{~m} \text { ); narrowing } \\
\text { (up to } 50 \mathrm{~m} \text { ); width of the river } \\
\text { decreased by } 17 \% \text { to } 45 \% \text {, while } \\
\text { its mean and maximum depth } \\
\text { increased by } 5 \% \text { to } 48 \%\end{array}$ & $\begin{array}{c}\text { Channel cut-offs; revetments and } \\
\text { groynes }\end{array}$ & $\mathrm{Csc}^{* * *} / \mathrm{Cfa}$ & [76] \\
\hline USA & $\begin{array}{l}\text { Widening (up to } 50 \% \text { ); } \\
\text { aggradation (less than } 1 \mathrm{~m} \text { ) }\end{array}$ & $\begin{array}{l}\text { Hard-rock mining; road } \\
\text { construction, timber harvest, } \\
\text { heavy grazing of uplands, } \\
\text { land-use change }\end{array}$ & $\mathrm{Csb} / \mathrm{Dsb}$ & [77] \\
\hline France & $\begin{array}{l}\text { Incision (up to } 5 \mathrm{~m} \text { ); narrowing } \\
\text { (up to } 22 \mathrm{~m} \text { ) }\end{array}$ & $\begin{array}{l}\text { Heavy grazing; land-use change; } \\
\text { gravel mining; check dams }\end{array}$ & $\mathrm{Cfb}$ & {$[31,77]$} \\
\hline Italy & $\begin{array}{l}\text { Incision ( } 3 \text { to } 4 \mathrm{~m} \text { and in some } \\
\text { cases more than } 10 \mathrm{~m} \text { ); narrowing } \\
\text { (up to } 50 \% \text { or more); changes in } \\
\text { channel pattern (from braided to } \\
\text { wandering) }\end{array}$ & $\begin{array}{l}\text { Gravel and sand mining; dams; } \\
\text { channelization }\end{array}$ & $\begin{array}{c}\mathrm{Cfa} / \mathrm{Cfb} / \mathrm{Csb} / \mathrm{Csa} / \\
\mathrm{Csc} / \mathrm{BSk}\end{array}$ & [11] \\
\hline
\end{tabular}

${ }^{*}$ Oceanic climate; ${ }^{* *}$ Warm-summer humid continental climate; ${ }^{* * *}$ Mediterranean cold summer climates.

This comparison suggests that Iranian rivers share several aspects with other rivers worldwide (e.g., type of adjustments, controlling factors). At the same time, some aspects are worthy of further detailed exploration, specifically the role of climate change on Iranian rivers.

Observations unequivocally show that Iran has been rapidly warming over recent decades, triggering a wide range of climatic changes. Iran has warmed by nearly $1.3^{\circ} \mathrm{C}$ during the period 1951 to $2013\left(+0.2^{\circ} \mathrm{C}\right.$ per decade), with an increase of the minimum temperature at a rate two times that of the maximum. Consequently, an increase in the frequency of heat extremes and a decrease in the frequency of cold extremes have been observed. The annual precipitation has decreased by $8 \mathrm{~mm}$ per decade, causing an expansion of Iran's dry zones. Previous studies have pointed out that warming is generally associated with more frequent heavy precipitation because warmer air can hold 
more moisture [78]. The percentages of areas with extremely dry and dry climate have increased by nearly $8 \%$ and $6 \%$, respectively, while a decreased percentage of Iran is now characterized by relatively wet climate $[78,79]$. Dry zones have been pushed into the southwest and northeast of Iran, which previously had a mostly semi-dry climate. Some areas in south Iran with a dry climate in the past have recently been characterized by an extremely dry climate. West Iran, which was previously characterized by a semi-wet climate, has recently become mostly semi dry [78]. It seems that the Central Basin and Persian Gulf and Oman Sea Basin and Sarakhs Basin have been affected by climate change, with as dryer climate being more common than other basins. That is why climate change is likely the major controlling factor of channel adjustments in these basins (e.g., rivers 7, 9, 11, and 15).

\subsection{Dataset Limitations and Research Perspectives}

It is worth noting that this work represents the first review about channel adjustments in Iranian rivers, and data turned out to be neither homogeneous nor complete for all the rivers. Some major limitations of the available dataset are: (i) Few data about bed-level changes, especially about channel aggradation, (ii) lack of reconstruction of evolutionary trajectory, and (iii) few case studies in some basins (e.g., Central, Eastern and Sarakhs basins). This implies that understanding channel adjustments, and their causes, could be improved notably by further studies. Reconstruction of evolutionary trajectory will be crucial for a sound understanding of factors controlling adjustments and for river management [80]. Moreover, the role of climate change in the recent evolution of Iranian rivers is a very challenging issue that future studies should address.

\section{Conclusions}

(1) Remarkable channel adjustments took place in Iranian rivers during the last few decades. Adjustments seem comparable with other rivers worldwide, although lack of evolutionary trajectories hinders a detailed analysis of timing and magnitude of morphological changes.

(2) Human interventions, specifically sediment mining and dams, have been the main causes of channel adjustment in several rivers, though climate change has played a major role in some rivers.

(3) Besides analyzing type, magnitude, and causes of channel adjustments, this review turned out to be useful for the identification of key issues that should be addressed in the future. More detailed studies will allow a better understanding of controlling factors, specifically to what extent climate change is driving the evolutionary trajectory of Iranian rivers.

Author Contributions: S.K. and N.S. designed the research. S.K. collected the data, made the first analyses, and wrote the first draft of the manuscript; N.S. contributed interpretation of the dataset and substantive manuscript writing.

Funding: This research was supported by Shahid Beheshti University G.C. with contract number S/600/688.

Conflicts of Interest: The authors declare no conflict of interest.

\section{References}

1. Brierley, G.J.; Fryirs, K. Geomorphology and River Management: Applications of the River Style Framework; Blackwell: Oxford, UK, 2005; 416p.

2. Grabowski, R.C.; Surian, N.; Gurnell, A.M. Characterizing geomorphological change to support sustainable river restoration and management. WIREs Water 2014. [CrossRef]

3. Gurnell, A.; Surian, N.; Zanoni, L. Multi-thread river channels: A perspective on changing European alpine river systems. Aquat. Sci. 2009, 71, 253-265. [CrossRef]

4. Hoyle, J.; Brooks, A.; Brierley, G.; Fryirs, K.; Lander, J. Spatial variability in the timing, nature and extent of channel response to typical human disturbance along the Upper Hunter River, New South Wales, Australia. Earth Surf. Processes Landforms 2008, 33, 868-889. [CrossRef]

5. Lie'bault, F.; Pie'gay, H. Assessment of channel changes due to long-term bedload supply decrease, Roubion River, France. Geomorphology 2001, 36, 167-186. [CrossRef] 
6. Scorpio, V.; Rosskopf, C.M. Channel adjustments in a Mediterranean river over the last 150 years in the context of anthropic and natural controls. Geomorphology 2016, 275, 90-104. [CrossRef]

7. Surian, N. Channel changes due to river regulation: The case of the Piave River, Italy. Earth Surf. Processes Landforms 1999, 24, 1135-1151. [CrossRef]

8. Vanacker, V.; Molina, A.; Govers, G.; Poesen, J.; Dercon, G.; Deckers, S. River channel response to short-term human- induced change in landscape connectivity in Andean ecosystema. Geomorphology 2005, 72, 340-353. [CrossRef]

9. Zhou, M.; Xia, J.; Lu, J.; Deng, S.; Lin, F. Morphological adjustments in a meandering reach of the middle YangtzeRiver caused by severe human activities. Geomorphology 2017, 285, 325-332. [CrossRef]

10. Chin, A.; O'Dowd, A.P.; Storesund, R.; Parker, A.; Roberts-Niemann, C. Response of step-pool mountain channels to wildfire under changing climate-fire regimes. In AGU Fall Meeting Abstracts; American Geophysical Union: San Francisco, CA, USA, 2013.

11. Surian, N.; Rinaldi, M. Morphological response to river engineering and management in alluvial channels in Italy. Geomorphology 2003, 50, 307-326. [CrossRef]

12. Gordon, E.; Meentemeyer, R.K. Effect of dam operation and land use on stream channel morphology and riparian vegetation. Geomorphology 2006, 82, 412-429. [CrossRef]

13. Liro, M. Gravel-bed channel changes upstream of a reservoir: The case of the Dunajec River upstream of the Czorsztyn Reservoir, southern Poland. Geomorphology 2015, 228, 694-702. [CrossRef]

14. Ma, Y.; Qing Huang, H.; Nanson, G.C.; Li, Y.; Yao, W. Channel adjustments in response to the operation of large dams: The upper reach of the lower Yellow River. Geomorphology 2012, 147-148, 35-48. [CrossRef]

15. Smith, N.D.; Morozova, G.S.; Pérez-Arlucea, M.; Gibling, M.R. Dam-induced and natural channel changes in the Saskatchewan River below the E.B. Campbell Dam, Canada. Geomorphology 2016, 269, 186-202. [CrossRef]

16. Takahashi, M.; Nakamura, F. Impacts of dam-regulated flows on channel morphology and riparian vegetation: A longitudinal analysis of Satsunai River, Japan. Landsc. Ecol. Eng. 2011, 7, 65-77. [CrossRef]

17. Kondolf, G.M. Geomorphic and environmental effects of instream gravel mining. Landsc. Urban Plan. 1994, 28, 225-243. [CrossRef]

18. Martin-Vide, J.P.; Ferrer-Boix, C.; Ollero, A. Incision due to gravel mining: Modeling a case study from the GJllego River, Spain. Geomorphology 2010, 117, 261-271. [CrossRef]

19. Baillie, B.R.; Davis, T.R. Effects of land use on the channel morphology of streams in the Moutere Gravels, Nelson, New Zealand. J. Hydrol. 2002, 41, 19-45.

20. Besn, P.; Ibisate, A. River channel adjustment of several river reaches on Ebro basin. Q. Int. 2015, 364, 44-53. [CrossRef]

21. Boyle, P.R. Morphologyin urbanized streams of the puget sound lowland. Master's Thesis, University of Maryland, College Park, MD, USA, 2004.

22. Booth, D.B. Stream channel incision following drainage basin urbanization. Water Resour. Bull. 1990, 26, 407-417. [CrossRef]

23. Clark, J.J.; Wilcock, P.R. Effects of land-use change on channel morphology in northeastern Puerto Rico. Geol. Soc. Am. Bull. 2000, 112, 1-15. [CrossRef]

24. Galster, J.C.; Pazzaglia, F.J.; Germanoski, D. Measuring the impact of urbanization on channel widths using historic aerial photographs and modern surveys. J. Am. Water Resour. Assoc. 2008, 44, 948-960. [CrossRef]

25. Grable, J.L.; Harden, G.P. Geomorphic response of Appalachian valley and Ridge stream to urbanization. Earth Surf. Processes Landforms 2006, 31, 1707-1720. [CrossRef]

26. Graf, W. Locational Probability for a dammed, urbanizing stream: Salt river, Arizona, USA. Environ. Manag. 2000, 25, 321-335. [CrossRef]

27. Kang, R.S. Effects of urbanization on channel morphology of three streams in the Central Red bed Plains of Oklahoma. Master's Thesis, Oklahoma University, Norman, OK, USA, 2007.

28. Kang, R.S.; Storm, D.E.; Marston, R.A. Downstream effects of urbanization on stillwater creek Oklahoma. Phy. Geograph. 2010, 31, 186-201. [CrossRef]

29. Karwan, D.L.; Allan, J.D.; Bergen, K.M. Changing near-stream land use and river channel morphology in the Venezuelan Andes. J. Am. Water Resour. Assoc. 2001, 37, 1579-1587. [CrossRef]

30. Kesstra, S.D.; Van Huissteden, J.; Vandenberghe, J.; Van Dam, O.; De Gier, J.; Dleizier, I.D. Evolution of the morphology of river Dragonja (SW Slovenia) due to land use changes. Geomorphology 2005, 69, 191-207. [CrossRef] 
31. Liébault, F.; Piégay, H. Causes of 20th century channel narrowing in mountain and piedmont rivers of southeastern France. Earth Surf. Processes Landforms 2002, 27, 425-444. [CrossRef]

32. Nelson, E.J.; Booth, D.B. Sediment sources in an urbanizing, mixed land-use watershed. J. Hydrol. 2002, 264, 51-68. [CrossRef]

33. Paul, M.J.; Meyer, J.L. Streams in the urban landscape. Annu. Rev. Ecol. Syst. 2001, 32, 333-365. [CrossRef]

34. Yousefi, S.; Pourghasemi, H.R.; Hooke, J.; Navratil, O.; Kidová, A. Changes in morphometric meander parameters identified on the Karoon River, Iran, using remote sensing data. Geomorphology 2016, 271, 55-64. [CrossRef]

35. Ward, J.V. Changing patterns of land use and basin morphometry: Impacts on stream geomorphology in the Illinois river basin northwest Arkansas 1941-2004. Ph.D. Thesis, University of Arkansas, Fayetteville, AR, USA, 2007.

36. Kiss, T.; Blanka, V. River channel response to climate- and human-induced hydrological changes: Case study on the meandering Hernád River, Hungary. Geomorphology 2012, 175-176, 115-125. [CrossRef]

37. Harsanto, P. River morphology modeling at the downstream of Progo River post eruption 2010 of Mount Merapi. Procedia Environ. Sci. 2015, 28, 148-157. [CrossRef]

38. Ulloa, H.; Iroum, A.; Picco, L.; Mohr, C.H.; Mazzorana, B.; Lenzi, M.A.; Mao, L. Spatial analysis of the impacts of the Chait_en volcano eruption (Chile)in three fluvial systems. J. S. Am. Earth Sci. 2016, 69, 213-225. [CrossRef]

39. Zheng, S.; Wu, B.; Thorne, C.R.; Simon, A. Morphological evolution of the North Fork Toutle River following the eruption of Mount St. Helens, Washington. Geomorphology 2014, 208, 102-116. [CrossRef]

40. Guan, M.; Carrivick, J.L.; Wright, N.G.; Andy Sleigh, P.; Staines, K.E.H. Quantifying the combined effects of multiple extreme floods on river channel geometry and on flood hazards. J. Hydrol. 2016, 538, 256-268. [CrossRef]

41. Hajdukiewicz, H.; Wyżga, B.; Mikuś, P.; Zawiejska, J.; Radecki-Pawlik, A. Impact of a large flood on mountain river habitats, channel morphology, and valley infrastructure. Geomorphology 2016, 272, 55-67. [CrossRef]

42. Righini, M.; Surian, N.; Wohl, E.; Marchi, L.; Comiti, F.; Amponsah, W.; Borga, M. Geomorphic response to an extreme flood in two Mediterranean rivers (northeastern Sardinia, Italy): Analysis of controlling factors. Geomorphology 2017, 290, 184-199. [CrossRef]

43. Benda, L.; Miller, D.; Bigelow, P.; Andras, K. Effects of post-wildfire erosion on channel environments, Boise River, Idaho. For. Ecol. Manag. 2003, 178, 105-119. [CrossRef]

44. Legleiter, C.J.; Lawrence, R.L.; Fonstad, M.A.; Marcus, W.A.; Aspinall, R. Fluvial response a decade after wildfire in the northern Yellowstone ecosystem: A spatially explicit analysis. Geomorphology 2003, 54, 119-136. [CrossRef]

45. Darehshouri, B.F.; Kasraian, N. Nature of Iran; Rowzaneh Kar Publication: Tehran, Iran, 1998.

46. Fahmi, H. An Overview of Water Resources Management in the IR of Iran; Ministry of Energy of Iran: Tehran, Iran, 2012.

47. Raziei, T. Köppen-Geiger climate classification of Iran and investigation of its changes during 20th century. J. Earth Space Phys. 2017, 43, 419-439. (In Persian)

48. Adib, A.; Foladfar, H.; Roozy, A. Role of construction of large dams on river morphology (case study: The Karkheh dam in Iran). Arabian J. Geosci. 2016, 9, 661. [CrossRef]

49. Asghari Sareskanroud, S. Analysis of the effects of gravel and sand mining on morphology of the Qarnqou River (from Sahand dam to Khorasank village). Hydrogeomorphology 2014, 1, 21-39. (In Persian)

50. Ashouri, M.; Piry, Z.; Rezaei Moghaddam, M.H. A comparison of the influence of the Sattarkhan reservoir dam on the upstream and downstream of the Ahar Chai River, NW Iran. Environ. Earth Sci. 2015, 73, 4099-4108. [CrossRef]

51. Borushke, I.; Hosseini, S.A. Investigation of morphological changes in Zarrinehrood River using geographic information system. J. Eng. Watershed Manag. 2016, 1, 14-104. (In Persian)

52. Ismaeili, R.; Hosseinzadeh, M.M.; Eghbali, R. The effects of gravel and sand mining on geomorphic characteristics of the Lavij River, Mazandaran Province. Geogr. Environ. Hazards 2013, 6, 57-70. (In Persian)

53. Kahrobaeiyan, P.; Behniafar, A.; Shakeri Zare, H.; Rezaei Arefi, M. Morphological evolution and meandering pattern of frontier river of Harirroodusing RS. Quant. Geomorph. Res. 2014, 3, 53-64. (In Persian) 
54. Khabbazi, M.; Oliyaei, A.; Al-Madrasi, A. Almetricgeometric parameters of the Dalaki River and its role in development and evolution of the meanders of the Arjan Plain. Quant. Geomorph. Res. 2015, 3, 112-126. (In Persian)

55. Khaleghi, S.; Surian, N.; Roostaei, S.; Khorshiddoust, A.M. Driving factors of short-term channel changes in a semi-arid area (Sahand Mountain, northwestern Iran). Environ. Earth Sci. 2015, 74, 6625-6637. [CrossRef]

56. Mohammadkhan, S.; Narmashiri, F.; Yazdanpanah, A. Investigating effect of the gravel and sand mining on river morphology (case study: Dehebala -Kerman River). Quant. Geomorphol. Res. 2016, 1, 14-26. (In Persian)

57. Nahvi, M.B.; Feizi, H. The study effect of gravel and sand mining from the TalarRiver bed. In Proceedings of the 8th International Conference on River Engineering, Ahvaz, Iran, 15-16 December 2009. (In Persian).

58. Rezaei Moghadam, M.H.; Piroozinejad, N. Investigating of channel changes and bank erosion in the Gamasiab River from 1955 to 2010. Geogr. Plan. 2014, 47, 109-134. (In Persian)

59. Rouzkhash, P.; Habibi, M.; Gharib Reza, M.R. Investigating the effects of gravel and sand mining from the Kan River in the south of the Resalat Bridge. In Proceedings of the 8th International Seminar of River Engineering, Ahvaz, Iran, 15-16 December 2009. (In Persian).

60. Sabzivand, R.; Najafi, A.; Mesbahi, J. Changes of River Morphology at the Entrance to the Plain, case study of Karoon River. In Proceedings of the 6th Iranian Hydraulic Conference, Shahrekord, Iran, 11-12 July 2007. (In Persian).

61. Shayan, S.; Sharifi Kia, M.; Dehestani, H. Extraction and measurement of the morphological changes of the Kashkan River due to the gravel and sand mining. Geogr. Space Q. 2013, 43, 191-207. (In Persian)

62. Yamani, M.; Goorabi, A.; Dowlati, J. The Effect of Human Activities on River Bank Stability (Case Study: Atrak River). Am. J. Environ. Sci. 2011, 7, 244-247. [CrossRef]

63. Yamani, M.; Sharafi, S. Geomorphology and effective factors in the bank erosion of the Horroud in Lorestan province. Geogr. Environ. Plan. 2012, 1, 15-32. (In Persian)

64. Vaezipour, H.A. Simulation of morphological changes of Sistan River (from Hirmand Plane to Zahak Dam). Master's Thesis, Shiraz University, Shiraz, Iran, 2011. (In Persian).

65. Zamani, E.; Mousavi, S.M. The Impact of gravel and sand mining on River Morphology (Case Study: Gravel mining from Khoshkehrood of Farsan). In Proceedings of the 7th International Seminar on River Engineering, Shahid Chamran University, Ahvaz, Iran, 13-14 February 2006.

66. Rashidi, M.; Hosseinzadeh, S.R.; Sepehr, A.; Zarei, H.; Khanehabad, M. Study of geomorphologic changes of Karoon River and its causes from 1954 to 2011 (1334 to 1391). Quant. Geomorphol. Res. 2016, 1, 43-59. (In Persian)

67. Yousefi, S.; Moradi, H.R.; Keesstra, S.; Pourghasemi, H.R.; Navratil, O.; Hooke, J. Effects of urbanization on river morphology of the Talar River, Mazandarn Province, Iran. Geocarto Int. 2017. [CrossRef]

68. Yousefi, S.; Moradi, H.R.; Pourghasemi, H.R.; Khatami, R. Assessment of floodplain landuse and channel morphology within meandering reach of the Talar River in Iran using GIS and aerial photographs. Geocarto Int. 2018, 33. [CrossRef]

69. Begueria, S.; Lopez-Moreno, J.; Gomez-Villar, A.; Rubio, V.; Lana-Renault, N.; Garcia-Ruiz, J. Fluvial Adjustments to soil erosion and plant cover changes in the Central Spanish Pyrenees. Geography 2006, 88, 177-186. [CrossRef]

70. Lu, X.X.; Zhang, S.R.; Xie, S.P.; Ma, P.K. Rapid channel incision of the lower Pearl River (China) since the 1990s as a consequence of sediment depletion. Hydrol. Earth Syst. Sci. 2007, 11, 1897-1906. [CrossRef]

71. Swanson, B.J.; Meyer, G.A.; Coonrod, J.E. Historical channel narrowing along the RioGrande near Albuquerque, New Mexico in response to peak discharge reductions and engineering: Magnitude and uncertainty of change from air photo measurements. Earth Surf. Processes Landforms 2011, 36, 885-900. [CrossRef]

72. Winterbottom, S.J. Medium and short-term channel planform changes on the Rivers Tay and Tummel, Scotland. Geomorphology 2000, 34, 195-208. [CrossRef]

73. Wishart, D.; Warburton, J.; Bracken, L. Gravel extraction and planform change in a wandering gravel-bed river: The River Wear, Northern England. Geomorphology 2008, 94, 131-152. [CrossRef]

74. Korpak, J. The influence of river training on mountain channel changes (Polish Carpathian Mountains). Geomorphology 2007, 92, 166-181. [CrossRef]

75. Wyżga, B. A review on channel incision in the Polish Carpathian Rivers during the 20th century. Gravel-Bed Rivers 2008, 6, 525-553. 
76. Kiss, T.; Fiala, K.; Sipos, G. Alterations of channel parameters in response to river regulation works since 1840 on the Lower Tisza River (Hungary). Geomorphology 2008, 98, 96-110. [CrossRef]

77. Kondolf, G.M.; Piégay, H.; Landon, N. Channel response to increased and decreased bedload supply from land use change: Contrasts between two catchments. Geomorphology 2002, 45, 35-51. [CrossRef]

78. Alizadeh-Choobari, O.; Najafi, M.S. Extreme weather events in Iran under a changing climate. Clim. Dyn. 2018, 50, 249-260. [CrossRef]

79. Sayari, N.; Bannayan, M.; Alizadeh, A.; Farid, A. Using drought indices to assess climate change impacts on drought conditions in the northeast of Iran (case study: Kashafrood basin). Meteorol. Appl. 2013, 20, 115-127. [CrossRef]

80. Brierley, G.J.; Fryirs, K. The use of evolutionary trajectories to guide "moving targets" in the management of river futures. River Res. Appl. 2016, 32, 823-835. [CrossRef]

(C) 2019 by the authors. Licensee MDPI, Basel, Switzerland. This article is an open access article distributed under the terms and conditions of the Creative Commons Attribution (CC BY) license (http://creativecommons.org/licenses/by/4.0/). 